\title{
Response to the paper "unraveling functional Neurology: an overview of all published documents by FR Carrick, including a critical review of research articles on its effect or benefit." by Marine Demortier and Charlotte Leboeuf-Yde
}

\author{
Frederick Robert Carrick ${ }^{1,2,3}$ (D)
}

A functional neurologic disorder is a prevalent and disabling condition at the intersection of neurology and psychiatry [1] with a current PubMed search of the term Functional Neurology (FN) listing 44,939 articles [2], 2618 Systematic Reviews [3] and 191 Meta-Analysis [4]. A PubMed search of my name and FN finds one publication addressing persistent vegetative state as a pejorative term [5] and another addressing the metrological performance of instruments used in clinical evaluation of balance [6]. However, Demortier and Leboeuf-Yde reviewed 121 of my publications through October, 2018 to measure the effect/benefit of treatment/intervention using a FN approach when I have not written anything on the subject.

Functional neurology represents a paradigm of healthcare that utilizes an evidence-based approach to quantify human performance and function. It does not represent a theory or hypotheses or any diagnostic or treatment modalities [7]. Demortier and Leboeuf-Yde state that the scientific basis of FN was my 1997 publication describing changes in the size of the blind spot by somesthetic stimulation [8] rather than my earlier publications addressing lumbar [9] and cervical radiculopathy [10]. However none of these works represent the scientific basis of FN. I did not suggest a clinical application to my observations of changes in the functional size of the physiological blind spot but others have recently demonstrated that it can also be shrunk through exercises with significant clinical applications [11].

There is an abundance of evidence-based literature reporting diagnostic and treatment modalities under a FN paradigm. Functional connectivity (FC) [2, 12-14], functional neuroanatomy of sequence learning [15], functional neural substrates of reward processing and inhibitory control [16], functional brain network connectivity [17], functional neurological characterization of disease [18], functional exercise capacity [19], utilization of functional magnetic resonance imaging (fMRI) scanning of cognitive tasks [20] are all components of a FN paradigm and the list goes on and on. While physical exercise is an evidence-based application within the paradigm of FN, it would not and should not be classified as a FN treatment. A search of the literature to discover an increase in muscle strength by a FN treatment would come up short and so it should. Gait and balance impairments are FN paradigm examples of treatable targets that can manage reduced functional mobility [21, 22] but they are not FN treatments.

In an attempt to find evidence for FN, the authors have elevated select empiricism over other forms of knowledge important to clinicians, patients and society. This is problematic in this case as their conclusions are made based upon a review of my published work that does not reflect the topic of their interest.

Correspondence: drfrcarrick@post.harvard.edu

${ }^{1}$ Professor of Neurology, University of Central Florida College of Medicine, Orlando, FL, USA

${ }^{2}$ Adjunct Professor, MGH Institute for Health Professions, Boston, MA, USA

Full list of author information is available at the end of the article 


\section{Acknowledgements}

None.

\section{Authors' contributions}

All. The author read and approved the final manuscript.

\section{Funding}

None.

\section{Availability of data and materials}

None.

\section{Ethics approval and consent to participate}

None Needed.

\section{Consent for publication}

I give consent to publish my letter in response as submitted.

\section{Competing interests}

None.

\section{Author details}

${ }^{1}$ Professor of Neurology, University of Central Florida College of Medicine, Orlando, FL, USA. ${ }^{2}$ Adjunct Professor, MGH Institute for Health Professions, Boston, MA, USA. ${ }^{3}$ Senior Research Fellow Centre for Mental Health Research (CMHR-CU) in association with University of Cambridge, Cambridge, UK.

Received: 30 October 2019 Accepted: 16 January 2020

Published online: 28 January 2020

\section{References}

1. Ospina JP, Jalilianhasanpour R, Perez DL. The role of the anterior and midcingulate cortex in the neurobiology of functional neurologic disorder. Handb Clin Neurol. 2019;166:267-79.

2. Functional Neurology PubMed Search. 2019. https://www.ncbi.n/m.nih.gov/ pubmed/?term=functional+neurology.)

3. Functional Neurology and Systematic PubMed Search. 2019. https://www ncbi.nlm.nih.gov/pubmed?term=functional+neurology+and+ systematic\&cmd=DetailsSearch.)

4. Functional Neurology Meta-Analysis PubMed Search 2019. https://www. ncbi.nlm.nih.gov/pubmed/?term=functional+neurology+and+metaanalysis.)

5. Machado C, Estevez M, Carrick FR, et al. Vegetative state is a pejorative term NeuroRehabilitation. 2012;31:345-7.

6. Carrick FR, Hankir A, Zaman R, Wright CHG. Metrological performance of instruments used in clinical evaluation of balance. Psychiatr Danub. 2019;31: 324-30

7. Carrick FR. Chiropractic Neurology. New York chiropractic college Neurology lecture; 1983; Islip. N Y.

8. Carrick FR. Changes in brain function after manipulation of the cervical spine. J Manip Physiol Ther. 1997;20:529-45.

9. Carrick FR. Treatment of the pathomechanics of the lumbar spine by manipulation. J Manip Physiol Ther. 1981;4:173-8.

10. Carrick FR. Cervical radiculopathy: the diagnosis and treatment of pathomechanics in the cervical spine. J Manip Physiol Ther. 1983;6:129-37.

11. Miller PA, Wallis G, Bex PJ, Arnold DH. Reducing the size of the human physiological blind spot through training. Current biology : CB. 2015;25: R747-8.

12. Briels CT, Stam CJ, Scheltens P, Bruins S, Lues I, Gouw AA. In pursuit of a sensitive EEG functional connectivity outcome measure for clinical trials in Alzheimer's disease. Clin Neurophysiol. 2019;131:88-95.

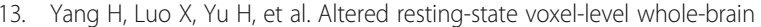
functional connectivity in multiple system atrophy patients with cognitive impairment. Clin Neurophysiol. 2019;131:54-62.

14. Ueda R, Takeichi $H$, Kaga $Y$, et al. Atypical gamma functional connectivity pattern during light sleep in children with attention deficit hyperactivity disorder. Brain Dev. 2019.

15. Huang $X$, Zhang D, Chen $Y$, et al. Altered functional connectivity of the red nucleus and substantia nigra in migraine without aura. J Headache Pain 2019;20:104
16. Janacsek K, Shattuck KF, Tagarelli KM, Lum JAG, Turkeltaub PE, Ullman MT. Sequence learning in the human brain: a functional neuroanatomical metaanalysis of serial reaction time studies. Neuroimage. 2019;116387.

17. Paz-Alonso PM, Navalpotro-Gomez I, Boddy P, et al. Functional inhibitory control dynamics in impulse control disorders in Parkinson's disease. Movement disorders : official journal of the Movement Disorder Society. 2019.

18. Su J, Ban S, Wang M, et al. Reduced resting-state brain functional network connectivity and poor regional homogeneity in patients with CADASIL. J Headache Pain. 2019;20:103.

19. Bauwens M Storch S, Weisschuh N, et al. Functional characterization of novel MFSD8 pathogenic variants anticipates neurological involvement in juvenile isolated maculopathy. Clin Genet. 2019.

20. von Siemens SM, Perneczky R, Vogelmeier CF, et al. The association of cognitive functioning as measured by the DemTect with functional and clinical characteristics of COPD: results from the COSYCONET cohort. Respir Res. 2019:20:257.

21. lancheva D, Trenova A, Mantarova S, Terziyski K. Functional magnetic resonance imaging correlations between fatigue and cognitive performance in patients with relapsing remitting multiple sclerosis. Frontiers in psychiatry. 2019;10:754.

22. Tosserams A, de Vries NM, Bloem BR, Nonnekes J. Multidisciplinary care to optimize functional mobility in Parkinson disease. Clin Geriatr Med. 2020;36: 159-72.

\section{Publisher's Note}

Springer Nature remains neutral with regard to jurisdictional claims in published maps and institutional affiliations.
Ready to submit your research? Choose BMC and benefit from:

- fast, convenient online submission

- thorough peer review by experienced researchers in your field

- rapid publication on acceptance

- support for research data, including large and complex data types

- gold Open Access which fosters wider collaboration and increased citations

- maximum visibility for your research: over $100 \mathrm{M}$ website views per year

At BMC, research is always in progress.

Learn more biomedcentral.com/submissions 